\title{
Corporate social responsibility and firm performance: evidence from manufacturing companies in Sri Lanka
}

\author{
Kengatharan, L., Jeyan Suganya, D.F. and Sulochani, R.G.R \\ Department of Financial Management, University of Jaffna, Sri Lanka
}

\begin{abstract}
Each sector faces high demand for Corporate Social Responsibility (CSR) to maximise share holders wealth for recent decades. The purpose of this study is to examine the impact of CSR on firm performance of manufacturing companies listed on Colombo Stock Exchange in Sri Lanka. In order to carry out this study 31 listed manufacturing companies were selected as sample among 40 companies. CSR activities are considered as explanatory variables which are divided into three dimensions such as economic, social and environmental activities. Tobin's $Q$ is used to measure firm performance while firm size and financial leverage are treated as control variables. Necessary data for this study were collected from financial statements of the respective companies for the period of five years from 2013 to 2018. Multiple regression analysis is used to test hypotheses to examine the impact of CSR on firm performance. The results of regression model reveals that there is a significant negative impact of economic activities, social activities and environmental activities on Tobin's $Q$. Finding of the study suggests that management of the company should focus more on CSR practices to attract more customers towards their product and it can increase firm value and shareholders' wealth of the firm in future. When the investors prefer the companies which have more consideration on CSR to invest their money, they can make higher earnings on their investment.
\end{abstract}

Keywords: economic activities, environmental activities, firm performance, social activities, Tobin $q$

\section{Introduction}

CSR is an important part for addressing role of the business in society and it has a significant direct and indirect impact on trend of business market. In competitive business world, every company must have a good relationship with every party for sustainable growth of a company. In past twenty years, there were a radical change among business and society. Key drivers of this changes have been globalization of trade, increased size and influence of companies, repositioning of government and rise in strategic importance of stakeholder relationships, knowledge and brand reputation. CSR is defined as responsiveness of business to stakeholders for their legal, ethical, social and environmental expectations (Omboto, 2014). According to the Global Reporting 
Initiative (GRI) guide lines, CSR is "being the way through which a company achieves a balance of economic environmental and social imperatives at the same time addressing the expectations of shareholders". The world business council for sustainable development (1999) stated that CSR is "the continuing commitment by business to behave ethically and contribute to economic development while improving the quality of life workforce and their families as well as of the local community and society at large". However CSR is not main goal of organization to satisfy all parties but its aim is to create economic and social value to their organization, for a shareholder, it might be to increase wealth or for the government to decrease unemployment and increase Gross Domestic Product by high volume production of organization (Ocran, 2011).

Most of business are doing CSR activities to get some benefits such as attracting, retaining and maintaining a happy workforce (employees), media interest and good reputation, access to funding opportunities, differentiating from competitors, saving money on operating cost, increase in customer retention, attracting more profitable investors and to obtain the reliability of government. Firm performances do not diminish the prospects of future persons to enjoy levels of consumptions, wealth, utility or welfare comparable to those enjoyed in the present. This means companies' operational activities reduce environmental damage and resource depletion and efforts to influence business practices toward economic sustainability include involve price mechanisms, such as carbon taxes that pass on the cost of environmental impact to the users of those resources (Jerkee, 2008). Corporation discloses its performance with respect to activities which have direct impact on the societal, environmental and economic performance of an organization (Owiti, 2013).

There are various opinions on CSR among various scholars. Milton Friedman (1970) who was a famous economist and debater argued that the firms should not focus on CSR activities unless it acts as a value creator and comply with the wishes of the company's shareholders. Campbell (2007) argued that CSR make strong relationship with wealth of company's shareholders. Further, said that, a firm using CSR tends to lower its capital constraints through better access to bank loans. Work actively with CSR increases the influence of various stakeholders. Due to those debates regarding CSR and its value creation capabilities, the interest among researchers to examine the impact of companies CSR activities on firm performance increases. Current business world engagement in CSR has become a common practice in most of countries. But CSR required some money and should grant a portion of valuable resource. So it is still a debatable issue in some countries. It may be a cause to result of lower profitable margin of the business. And, in this competitive market situation, those money and resources will be useful in generating more income than being socially responsible. Then, most of the companies do CSR activities to fulfil legal regulation and to enhance some reputation.

Most of prior studies done on CSR have focused on companies in developed countries (Tsoutsoura, 2004; Chand, 2006; Fauzi, 2007; Young and Thyil, 2009; 
McGehee et al, 2009 and Cornett et al, 2014) and there are limited numbers of studies on CSR using the context of developing countries such as Sri Lanka (Nimsith et al., 2017; Abeysinghe and Basnayake, 2016; Lakshitha and Perera, 2016 and Wijesinghe, 2012). So, impact of CSR may be different from developing countries to developed countries. Finding of the studies done in other countries cannot be generalised in other countries. Analysing process of CSR in Sri Lankan companies is still in infant level. Because most of the companies are categorised under small and medium level while comparing with the size and turnover of companies located in developed countries. Therefore, they may think that practicing CSR activities may require larger amount of money and larger part of the profit will be spent on CSR activities. Further, the manufacturing sector is very special than other sectors as it directly involves with the changes of economy and environment of the country. Population of listed manufacturing companies are larger than listed companies under other sectors in Sri Lanka and it contributes much to environmental pollution and social cost than other sectors in the world. Therefore, this study is conducted with the purpose of examining the impact of CSR on firm performance of manufacturing companies in Sri Lanka.

\section{Literature Review}

CSR is one of key drivers for sustainability of the business. Sustainability is about building a society in which a proper balance is created between economic, social and environmental aims. It leads for sustaining and expanding economic growth, shareholders' wealth, prestige, goodwill, corporate reputation, customer relationships and quality of product and services. CSR is a self regulating business model It motivates a company to be socially accountable to itself, its stakeholders, and the public. Companies can be aware of the kind of impact they are having on all aspects of society, including economic, social, and environmental.

\section{Economic Dimension}

It considers the effects of business activities on economic conditions of its stakeholders and on economic systems at local, national and global levels (You, 2015). Meeting economic responsibility is the first layer of responsibility in CSR in the way of providing goods and services at reasonable price to customers, favourable return to investors, and reliable compensation to workers for surviving at the market for long term. Enterprises are aware that their survival in today's market depends on sacrifice short-term profits due to the positive effects in the future, which satisfy the owners and managers, not just as they used to maximize profits. It provides direct and indirect economic impact on communities through spending power and geographic, economic factors such as business process, outsourcing, knowledge, innovation, social investments in employees and consumers, taxes, tax incentives, wages, pensions and other benefits paid to employees (Nasrullah and Rahim, 2014).

\section{Social Dimension}

The relationship between business and society indicates social dimension of CSR. It may involve sourcing fair trade products, such as agreeing to pay employees a reasonable wage and taking effort that benefit society, for instance using resources to organize charitable fundraisers. Hillman 
and Kein (2001) stated that society is a series of social contracts between members of society and the society itself. Looking from the perspective of CSR, another possibility of businesses acting in a responsible manner besides their commercial interest is that society implicitly expects them to operate responsibly. This concept is identified behind the Integrated Social Contracts Theory which was developed by Hillman and Kein (2001) to assist managers while taking decisions in the ethical context.

\section{Environmental Dimension}

Humans' negative impact on the environment has been frequently discussed in the global forum for the past several decades. Considering the increase in public interest in terms of company's environmental impact, it becomes more important for companies to consider the environmental consequences of its actions (Hart, 1995). Originally, the concept of CSR was mostly concerned with social responsibility (community-based programs, employments rights, etc.) but has in recent years shifted more towards corporations' environmental responsibilities (emission, water pollution etc.) and has become an essential part of CSR (Flammer, 2012). This is line with the finding of Flammer (2012), which indicate that shareholders often react positively to company's eco-friendly initiatives and negatively towards those that in some form affects the environment in a destructive way. It has also been indicated that environmentally well-performing firms are rewarded by customers as the perceived value of such companies is higher than that of companies which are less environmentally friendly.

Instrumental or economic aspect of CSR suggests that firms will improve their return on investment only when they engage in pro-social or ethical conduct beyond what is required by law. The term "instrumental" reflects the idea that the obligation of managers is to promote shareholders and wealth regardless of ethical considerations (Arnold, and Valentin, 2013). Bansal (2005) reiterated that the dramatic growth in the number of institutes, mutual funds, and online resources along with other publications, which specialize in encouraging corporations to improve their practices according to various responsibility criteria has led to a growth of CSR. Moreover, large institutional investors also give preference to investing in those firms which pursue socially responsible activities. Bansal (2005) reviewed many CSR studies and understood that whether CSR is priced by capital markets or not is unexplored. They join the league of scholars such as Hillman and Keim (2001) and MCWilliams who in their research directly examined how CSR influences firm's cost of equity capital. The study of scholars such as Brammer and Millington (2008), and Goss and Roberts (2011) analyzed the implications of CSR on the cost of equity capital. On similar lines, Ghoul et al. (2011) also in their study attempted to understand whether CSR affects the firm's cost of equity capital. The results revealed that firms with high CSR activities should have lower cost of capital than firms with low CSR activities. Also, firms with low CSR activities have a reduced investor base and higher perceived risk.

In Sri Lanka, Lakshitha and Perera (2016) carried out a study to the relationship between CSR practice and financial performance of manufacturing companies 
and revealed the results that CSR activities have significant negative relationship with return on assets and net profit margin. However, Nimsith et al. (2017) found that there is a positive significant relationship between CSR activities and financial performance of banking industry in Sri Lanka. Further, in line with the result, they recommended that banks should portray themselves as socially responsible firms to improve the overall financial performance of the banks. Nevertheless, Abeysinghe and Basnayake (2016) revealed there is a significant negative relationship between CSR disclosures and financial performance of domestic commercial banks in Sri Lanka. Further they identified that CSR disclosure level in private banks is higher than the state banks even though the firm size of private banks are smaller than the state banks. Wijesinghe (2012) intended to analyse disclosure of CSR in Sri Lanka with GRI guidelines to measure the level of disclosure and researcher concluded that overall level of CSR disclosure is at a low level and there is a need of much improvement in governance, economical, social and environmental disclosures since those are the major components of sustainability. Researcher further observed that there are deviations in the level of disclosure among different industry sectors. According to the literature analysed, studies done in Sri Lanka on various industries in different years revealed contradict result. Therefore, It is important to analyse CSR practice in Sri Lanka to reveal how it has an impact on firm performance time to time.

According to the findings of previous literature following hypotheses are formulated to test with statistical analysis.
$\mathrm{H}_{1}$ : There is a significant impact of economic activity on firm performance.

$\mathrm{H}_{2}$ : There is a significant impact of social activity on firm performance.

$\mathrm{H}_{3}$ : There is a significant impact of environmental activity on firm performance.

\subsection{Methodology}

\subsection{Population and Sampling}

There are 298 companies listed under 20 business sectors of Colombo Stock Exchange as at $29^{\text {th }}$ of March 2018. Manufacturing sector consists 40 companies. Only 31 manufacturing companies were selected as sample using convenient sampling method among the population. Because, rest of the companies have not stated to practice CSR activities and some of them have not revealed those practices in their annual report. Newly listed companies have been excluded from the survey as data was collected for 5 years data for the empirical survey. Manufacturing companies gives the significance contribution to the national Gross Domestic Product of the country as it consists larger number of population than other sectors listed in CSE.

\subsection{Data Collection}

Data were collected from the annual reports of sample companies for the five consecutive financial years from 2013 to 2018 which are available on the CSE's Website. Secondary data for the study were drawn from audited accounts (i.e. income statements and balance sheets) of the concerned companies as fairly accurate and reliable. Therefore these data may be considered reliable for the study. 


\subsection{Measurement of Variables}

Independent variable CSR is measured using its different dimensions such as economic, social and environmental activities under various indicators as given in the table below. Dependent variable of the study is Tobin's Q used to measure firm performance. Firm size and financial leverage are treated as control variables with the given measurement.

Table 1 : Measurement of Variables

\begin{tabular}{|c|c|c|}
\hline Economic Activity & Social Activity & Environmental Activity \\
\hline $\begin{array}{l}\text { 1. Product development } \\
\text { 2. Product / service quality } \\
\text { 3. Product / service safety } \\
\text { 4. Corporate governance } \\
\text { 5. Supplier relation / } \\
\text { engagement } \\
\text { 6. Customer relation / } \\
\text { satisfaction } \\
\text { 7. Stakeholder engagement } \\
\text { 8. Other stakeholders' matters } \\
\text { 9. Marketplace awards }\end{array}$ & $\begin{array}{l}\text { 1. Education } \\
\text { 2. Charity } \\
\text { 3. Art, culture and heritage } \\
\text { 4. Equality in community } \\
\text { 5. Youth development and } \\
\text { graduate employment } \\
\text { programme } \\
\text { 6. Employees participation in } \\
\text { community service } \\
\text { 7. Community health and } \\
\text { safety } \\
\text { 8. Community and } \\
\text { infrastructure support } \\
\text { 9. Community awards } \\
\text { 10. Community } \\
\text { engagement } \\
\text { 11. Support for national } \\
\text { pride / government } \\
\text { sponsored campaigns }\end{array}$ & $\begin{array}{l}\text { 1. Pollution control / } \\
\text { abatement } \\
\text { 2. Environmental } \\
\text { conservation and repairs } \\
\text { 3. Energy conservation } \\
\text { 4. Resource conservation } \\
\text { and waste management } \\
\text { 5. ISO } 14001 / 14004 \\
\text { (Environmental } \\
\text { Management System) } \\
\text { certification } \\
\text { 6. Environmental awards } \\
\text { 7. Other commitments } \\
\text { towards environmental } \\
\text { protection / sustainability }\end{array}$ \\
\hline
\end{tabular}

\begin{tabular}{|l|l|}
\hline \multicolumn{1}{|c|}{ Variables } & \multicolumn{1}{c|}{ Measurement } \\
\hline Tobin's Q & $\frac{\text { Market value }+ \text { Debt }}{\text { Total assets }}$ \\
\hline Firm size & $\frac{\log \text { (Total assets) }}{\text { Total debt }}$ \\
\hline Financial leverage & Total assets \\
\hline
\end{tabular}

Regression model of the study is as follows:

$T Q=\beta_{0}+\beta_{1} E C O_{i t}+\beta_{2} S O C_{i t}+\beta_{1} E N V_{i t}+\beta_{4} F Z_{i t}+\beta_{3} F L_{i t}+z$

TQ :Tobin's Q

ECO : Economic Activities

SOC : Social Activities

ENV : EnvironmentActivities

FZ : Size of the firm

FL : Leverage

$\varepsilon \quad:$ Error term.

it $\quad$ :For firm $\mathrm{i}$ in period $\mathrm{t}$

$\beta_{0} \quad$ : Intercept 


\section{Empirical Result}

\subsection{Descriptive Statistics}

Table 2 shows descriptive statistics of all variables based on 155 observations. Mean value signifies average of value of data set and standard deviation explains the possible range the values in the data set can be deviate around the mean relevant to the variable.

Table 2: Descriptive statistics

\begin{tabular}{|l|r|r|r|r|r|r|}
\hline & Tobin's Q & \multicolumn{1}{c|}{ ECO } & \multicolumn{1}{c|}{ SOC } & ENV & \multicolumn{1}{c|}{ FZ } & \multicolumn{1}{c|}{ FL } \\
\hline Mean & 0.723 & 1.832 & 2.691 & 1.038 & 9.407 & 0.649 \\
\hline Median & 0.560 & 2.000 & 2.851 & 1.037 & 9.360 & 0.570 \\
\hline Maximum & 2.910 & 3.000 & 4.074 & 1.814 & 10.970 & 1.740 \\
\hline Minimum & 0.040 & 0.000 & 0.407 & 0.259 & 8.000 & 0.040 \\
\hline Std. Dev. & 0.552 & 0.504 & 0.689 & 0.355 & 0.593 & 0.416 \\
\hline Skewness & 1.821 & -0.687 & -0.450 & -0.178 & -0.050 & 0.635 \\
\hline Kurtosis & 6.442 & 4.750 & 3.178 & 2.209 & 2.753 & 2.654 \\
\hline Jarque-Bera & 162.279 & 32.000 & 5.442 & 4.858 & 0.458 & 11.196 \\
\hline Probability & 0.000 & 0.000 & 0.065 & 0.088 & 0.795 & 0.003 \\
\hline Sum & 112.130 & 284.000 & 417.185 & 161.000 & 1458.206 & 100.620 \\
\hline Sum Sq. Dev. & 46.979 & 39.194 & 73.196 & 19.42481 & 54.269 & 26.767 \\
\hline
\end{tabular}

According to the mean value of CSR indicators, social responsibilities are paid more attention by the selected companies than other economic and environmental responsibilities as it has higher mean value (2.691), maximum value (4.074) and minimum value (0.407). The data shows that companies are practising CSR in low level as mean value of all indicators reveals lower value compared to total number of indicators in each dimension. It can be identified that there is no extreme value or outliers in the data set since value of standard deviation is at the lower value below 0.7 .

\subsection{Correlation Analysis}

Correlation analysis is employed for purposes of determining the relationship between independent and dependent variables. 
Table 3: Correlation matrix

\begin{tabular}{|c|c|c|c|c|c|c|}
\hline & TQ & ECO & SOC & ENV & FZ & FL \\
\hline TQ & 1.000 & & & & & \\
\hline \multirow[t]{2}{*}{ ECO } & $-0.249 * *$ & 1.000 & & & & \\
\hline & 0.001 & & & & & \\
\hline \multirow[t]{2}{*}{ SOC } & $-0.373 * *$ & 0.089 & 1.000 & & & \\
\hline & 0.000 & 0.268 & & & & \\
\hline \multirow[t]{2}{*}{ ENV } & $-0.207 * *$ & 0.170 & -0.085 & 1.000 & & \\
\hline & 0.009 & 0.033 & 0.288 & & & \\
\hline \multirow[t]{2}{*}{$\mathbf{F Z}$} & -0.159 & 0.158 & 0.148 & -0.113 & 1.000 & \\
\hline & $0.048 *$ & 0.048 & 0.064 & 0.158 & & \\
\hline \multirow[t]{2}{*}{ FL } & -0.096 & 0.053 & 0.109 & -0.082 & 0.283 & 1.000 \\
\hline & 0.232 & 0.504 & 0.173 & 0.305 & 0.000 & \\
\hline
\end{tabular}

** correlation is significant at the 0.01 level, * correlation is significant at the 0.05 level

According to that table 3, components of CSR economic, social and environmental activities have significant negative relationship with Tobin's Q at $99 \%$ confident level $(\mathrm{r}=-0.249,-0.373$ and -0.207 respectively. However, each variable has week relationship with dependent variable since entire value of correlation coefficient is below 0.5 . Firm size has significant negative relationship with Tobin's $\mathrm{Q}$ at 0.05 level while financial leverage doesn't have any significant relationship with Tobin's Q.

\subsection{Regression Analysis}

Multiple regression analysis is used to measure the impact of independent variables (Environment activities, Social activities and Environment activities) on dependent variable (Tobin's Q)

Table 4: Multiple regression analysis

\begin{tabular}{|c|r|r|r|r|}
\hline Dependent variable: Tobin's Q & Coefficient & Std. Error & t-Statistic & Prob. \\
\hline Constant & 3.045 & 0.668 & 4.557 & 0.000 \\
\hline ECO & -0.176 & 0.080 & -2.182 & 0.030 \\
\hline SOC & -0.288 & 0.058 & -4.950 & 0.000 \\
\hline ENV & -0.349 & 0.114 & -3.056 & 0.002 \\
\hline FZ & -0.087 & 0.070 & -1.233 & 0.219 \\
\hline FL & -0.053 & 0.099 & -0.536 & 0.592 \\
\hline
\end{tabular}




\begin{tabular}{|l|r|l|r|}
\hline R-squared & 0.240 & Mean dependent var & 0.723 \\
\hline Adjusted R-squared & 0.214 & S.D. dependent var & 0.552 \\
\hline S.E. of regression & 0.489 & Akaike info criterion & 1.446 \\
\hline Sum squared resid & 35.681 & Schwarz criterion & 1.564 \\
\hline Log likelihood & -106.103 & Hannan-Quinn criter. & 1.494 \\
\hline F-statistic & 9.435 & Durbin-Watson stat & 1.573 \\
\hline Prob(F-statistic) & 0.000 & & \\
\hline
\end{tabular}

Source: Developed by researcherAccording to the table 4 , value of $\mathrm{R}$ squared 0.240 suggests that $24 \%$ variability of the Tobin's Q can be explained by selected independent variables. As well as it indicates that there are some other factors which explain $76 \%$ variability of Tobin's Q. Regression model developed for this study is identified significant since $\mathrm{p}$ value is below 0.05 . Further, table shows that economic activity has significant negative impact on Tobin's $Q$ at 0.05 level $\quad(\beta=-0.176, p<0.05)$. It leads to support $\mathrm{H}_{1}$ states that there is a significant impact of economic activity on firm performance. Social and environmental activities also have significant negative impact on Tobin's $Q$ at 0.01 level $(\beta=-0.288, p<0.01, \beta=-0.349$, $\mathrm{p}<0.01$ respectively). $\mathrm{H}_{2}$ states there is a significant impact of social activity on firm performance and $\mathrm{H}_{3}$ states there is a significant impact of environmental activity on firm performance supports to the findings of the study. Firm size and financial leverage don't have any significant impact on firm performance as $p$ value is not less than 0.05 .

Findings of the study are consistent with Friedman's viewpoint in 1970 that the only obligation of business is to utilize its resources in a way which helps to increase the profit and share of the owners of firm. It is believed that including in CSR is an extra cost to the firm, thus the firm performance goes low. As Cochran (2007) argued, if certain actions that are classified as socially responsible are negatively associated with the firm performance, then the managers are advised to be cautious. Research done by Lakshitha and Perera (2016) revealed similar result that there is a significant on manufacturing companies.

\section{Conclusion}

The objective of this study is examining the impact of CSR activities on firm performance of manufacturing companies listed on CSE. For the purpose of testing hypotheses, relevant data were collected from annual reports of respective companies from 2013 to 2018. Descriptive statistics, correlation analysis and multiple regression analysis were employed. According to the findings, economic activities, social activities and environmental activities have significant negative impact on Tobin's Q. However, most of the studies carried out to test impact of CSR on firm performance revealed positive relationship. In Sri Lanka, most of the indicators under each dimension of CSR have not been practiced by larger number of companies in Sri Lanka as mean value of each variable is very low. Most of the firms have not started to practice CSR activities and revealed in the annual report. 
Therefore, result of this study may not be as expected based on the previous findings of the studies. The main contribution of this study is to find the impact of CSR activities on firm performance of a company. It will be very useful to managers to adjust their CSR activities to fit with their highest firm performance. This study will contribute to fill the research gap and extent the literature. Future studies can be carried out on examining CSR by taking sample companies which are practicing CSR activities for a long term to find more accurate result.

\section{Reference}

Abeysinghe, A.M.I.P., \& Basnayake, W.B.M.D. (2016). Relationship between corporate social responsibility disclosure and financial performance in Sri Lankan domestic banking industry. Interdisciplinary journal of contemporary research journal in business, (4)2, 37- 46.

Arnold, D., \& Valentin, A. (2013). Coporate Social Responsibility. Journal of Business Research , 66(10) ,1904-1914.

Bansal, P. (2005). Evolvin sustainability:A study of corporate sustainable development. Strategic management journal, 26(3), 197-218.

Brammer, \& Millington. (2008). Coporate Social Responsibility and earnings forecasting unbiasedness. Journal of Banking \& Finance. 18, 587-604.

Campbell, J. (2007). Why would corporations behave in socially reponsibility ways?. An institunal theory of coporate social responsibility, 37(2), 221-228

Chand, M. (2006). The Relationship between Corporate Social Performance and Corporate Financial Performance: Industry Type as a
Boundary Condition.

Cochran, P. (2007). The evolution of corporate social responsibility. Business Horizons.

Cornett, M. M., Erhemjamts, O., \& Tehranian, H. (2014). Corporate Social Responsibility and its Impact on Financial Performance:Investigation of U.S. Commercial Banks.

Fauzi, H. (2007). Corporate Social and Financial Performance: Empirical Evidence from American Companies. 119.

Flammer, C. (2012). Corporate social responsibility and shareholder reaction. The environmental Awareness of investors' Academy of Management Journal, 7(2), 295-309

Friedman, M. (1970). The Social responsibility of business is to increase its profits. New York Times Magazine, September 13.

Ghoul, S., Guedhami, O., Kwok, C., \& Mishra, D. (2011). Does coporate social responsibility affect the cost of capital?. Journal of banking \& Finance , 5(9), 2388-406.

Global Reporting Initiative. (2000-2013). Global Reporting Initiative G3,G3.1, G4. Global Reporting Initiative Organization.

Goss, A., \& Roberts, G. (2011). The impact of coporate social responsibility on the cost of bank loans. Journal of banking \& finance, 35(7), 1794-1810.

Hart, S. (1995). A natural-Resource-Based View of the firm. Academy of Management Reciew, 39(3), 254-280

Hillman, \& Kein. (2001). Competition Motivated. Journal of business research, 30(4), 777-98

Jerkee, J. (2008). Building trust in projectstakeholder relationships. Baltic 
Journal od Management, 3(1),7-22.

Lakshitha, W.R., \& Perera, H.A.P.L. (2016).

Impact of Corporate Social

Responsibility on Firm Financial

Performance: Evidence from the Listed

Manufacturing Companies in Sri Lanka.

In Proceedings of the Undergraduates

Research Conference - 2016 ,

Department of Accountancy, Faculty of

Commerce and Management Studies,

University of Kelaniya, Sri Lanka.

Mc Williams, J., \& Siegel, T. (2000). Coporate social responsibility and firm financial performance. Academy of management journal, 31(40), 854-72.

McGehee, N., Wattanakamolchai, S., Perdue, R., \& Calvert, E. (2009). Corporate Social Responsibility within the U.S. Lodging Industry: An Exploratory Study. Journal of Hospitality \& Tourism Research, 3(3), 417-37.

Nasrullah, N. M., \& Rahim, M. M. (2014). CSR in Private Enterprises in Developing Countries: Evidences from the Ready-made Garments Industry in Bangladesh. Retrieved from https://www.springer.com/978-3-31902349-6

Nimsith, S. I., Mafaza, M.H.F., \& Safna, H.M.F. (2017). Effect of corporate social responsibility on financial performance of banks in Sri Lanka. South Eastern University Arts Research Session 2016, $12-24$

Ocran, E. (2011). The effect of corporate social responsibility (CSR) on performance of multinational companies.A case study of Nestle Ghana Limited. MBA Thesis.Kwame Nkrumah university. 67(3),305-316.

Omboto, P. (2014). Adoption of Blue Ocean Strategy in CSR by Commercial Bank of Africa. unpublished MBA Thesis University of Nairobi,Kenya. 23(1),6591

Owiti, W. (2013). Effects of Corporate Social Responsibility on Company image ,university of Nairobi. unpublished MBA Project.

Tsoutsoura, M. (2004). Corporate social responsibility and financial performance, University of California, Berkeley.

Wijesinghe, K. N. (2012). Current context of disclosure of corporate social responsibility in Sri Lanka. Procedia Econ Finance, 2, 171-178

World Business Council for Sustainable Development. (1999), CSR definition, $\mathrm{h} \quad \mathrm{t} \quad \mathrm{t} \quad \mathrm{p} \quad \mathrm{s} / \mathrm{l}$ www.wbcsd.org/workprogram/business -role/previous-work/corporatesocialresponsibility. aspx.

You, J. (2015). Legal perspectives on corporate social responsibility: Lessons from the United States and Korea. New Delhi: Springer

Young, S., \& Thyil, V. (2009). Governance, Employees and CSR: Integration is the Key to Unlocking Value Asia Pacific, Journal of Human Resources, 47(2), 167-85. 